\title{
Comparative analysis of residential building $75 \%$ energy efficiency design standards of Shandong Province and Germany building energy efficiency standards
}

\author{
Li Zhen1,a, Shi Jinlei2,b \\ 1Shandong Academy of Building Research,Jinan,250031,China \\ 2Shandong Academy of Building Research,Jinan,250031,China \\ aemail : Lizhenn4014@sina.com, ${ }^{\mathrm{b}}$ email : shijinglei1987@163.com
}

Keywords: Residential building Energy saving design standardEnergy efficiency

\begin{abstract}
Efficiency design standard for residential building of Shandong Province should be improved by comparing current residential building 75\% energy efficiency design standards of Shandong Province with Germany relevant standard. Taking certain multi-story residential building as an example, the paper calculates heating demand in 75\% energy efficiency design standards of Shandong Province, Germany building design standards in 2002 and 2009 and passive house energy efficiency design standards. It discusses possible technical route diagrams for improving building energy efficiency design standards of Shandong Province, including countermeasures such as high performance building envelope thermal insulation materials, reducing proportion of energy consumption by fresh air and improving building overall air tightness.
\end{abstract}

\section{Foreword}

In order to carry out building energy efficiency work, our country increases the requirements of building energy efficiency design standards gradually. After Beijing took the leading to implement residential building 75\% energy efficiency design standard in 2012, Shandong, Tianjin, Xinjiang, Hebei, etc issued the standards on energy efficiency $75 \%{ }^{[1-4]}$.

Developed countries that have similar climatic conditions as northern area of our country are leading in building energy efficiency aspect, so it is necessary to research the gap between $75 \%$ energy efficiency standards and those of developed countries so as to provide technical route diagrams of improving building energy efficiency.

The paper will, on the basis of comparing the differences between Germany building energy efficiency design standards and energy efficiency standards of Shandong Province, get clear understanding of the gap between building energy efficiency standards of Shandong Province and those of developed countries. Then taking certain multi-story residential building of Jinan area as example, it compares on the stipulations of current 75\%residential building energy efficiency design standards of Shandong Province (referring to as residential building energy efficiency design standards hereinafter), Germany building energy efficiency design standards in 2002 and 2009 and passive house, and finds main bottleneck problems on further improving building energy efficiency rate according to development mode of building energy efficiency standards of our country; finally, while proposing the countermeasures, it gives out suggestions on technical routes for further improving residential building energy efficiency level of Shandong Province. 


\section{Comparison between residential building energy efficiency design standards of Shandong Province and Germany corresponding standards}

Comparison of weather conditions

Germany is located in the middle of Europe, belongs to north temperate climate, and has similar latitude to that in the north of Harbin City in Northeast China. However, its climatic conditions are more similar to North China. When researching and designing building energy consumption and heating, climatic conditions of Wurzburg is normally used as average climatic conditions of Germany. Heating degree day of the city is $3,500{ }^{\circ} \mathrm{C} \cdot \mathrm{d}$ (using $20^{\circ} \mathrm{C}$ is reference temperature) ${ }^{[5]}$.

heating degree day of 17 prefecture-level cities of Shandong Province (using $18^{\circ} \mathrm{C}$ as reference temperature) is $2,165-2,604{ }^{\circ} \mathrm{C} \cdot \mathrm{d}$, wherein that of Jinan is $2,211{ }^{\circ} \mathrm{C} \cdot \mathrm{d}$. If using $20^{\circ} \mathrm{C}$ as reference temperature, annual heating degree day of Jinan is $2,638{ }^{\circ} \mathrm{C} \cdot \mathrm{d}$. Heating degree day of Shandong Province is less than that of Germany, about 75\% of that of Germany. Under same building thermal insulation conditions, Germany shall consume more energy when reaching same room temperature. Development course of Germany building energy efficiency standards

Evolution of Germany building energy efficiency standards is shown in Table 1.

Table 1Evolution of Germany building energy efficiency standards

\begin{tabular}{|c|c|c|}
\hline Year & Standard name & Main feature \\
\hline 1994 & $\begin{array}{c}\text { Regulations on Building Energy } \\
\text { Efficiency Thermal Insulation }\end{array}$ & $\begin{array}{c}\text { Propose annual heating terminal energy } \\
\text { consumption limit value, and improve envelope } \\
\text { K value }\end{array}$ \\
\hline 2002 & $\begin{array}{c}\text { "Regulations on Building Energy } \\
\text { Efficiency” EnEV2002 }\end{array}$ & $\begin{array}{c}\text { Propose primary energy limit value. Decrease } \\
\text { heating terminal energy consumption by 30\% } \\
\text { on the basis of that in 1994. }\end{array}$ \\
\hline 2004 & EnEV2004 & Add contents of energy certificate \\
\hline 2009 & EnEV2007 & $\begin{array}{c}\text { Introduce public building energy consumption } \\
\text { limit value }\end{array}$ \\
\hline 2014 & EnEV2009 & $\begin{array}{c}\text { Further decrease annual heating and hot } \\
\text { water terminal energy consumption by 30\%. }\end{array}$ \\
\hline
\end{tabular}

In February 2002, Germany implemented new building energy efficiency norm EnEV2002. Core concept of the new building energy efficiency technical norm is to make system control on real energy consumption of building from controlling the lowest thermal insulation index of building envelope in certain aspect so as to make strict and effective energy consumption control. Maximum primary energy consumption of EnEV2002 is shown in Table 2. 
Table 2 Maximum primary energy consumption of EnEV2002

\begin{tabular}{|c|c|c|}
\hline \multirow{2}{*}{$\begin{array}{c}\text { Building } \\
\text { shape } \\
\text { coefficient }\end{array}$} & Anit usable area energy consumption & $\begin{array}{c}\text { Energy consumption of unit heating } \\
\text { volume }\end{array}$ \\
\cline { 2 - 3 } & $\begin{array}{c}\text { Normal residential building } \\
\mathrm{kWh} /\left(\mathrm{m}^{2} \cdot \mathrm{a}\right)\end{array}$ & $\begin{array}{c}\text { Non-residential building } \\
\mathrm{kWh} /\left(\mathrm{m}^{2} \cdot \mathrm{a}\right)\end{array}$ \\
\hline$\leq 0.2$ & $66.0+2,600 /(100+\mathrm{An})$ & 14.72 \\
\hline 0.3 & $73.53+2,600 /(100+\mathrm{An})$ & 17.13 \\
\hline 0.4 & $81.06+2,600 /(100+\mathrm{An})$ & 19.51 \\
\hline 0.5 & $88.58+2,600 /(100+\mathrm{An})$ & 21.95 \\
\hline 0.6 & $96.11+2,600 /(100+\mathrm{An})$ & 24.36 \\
\hline 0.7 & $103.64+2,600 /(100+\mathrm{An})$ & 26.77 \\
\hline 0.8 & $111.17+2,600 /(100+\mathrm{An})$ & 29.18 \\
\hline 0.9 & $118.70+2,600 /(100+\mathrm{An})$ & 31.59 \\
\hline 1.0 & $126.23+2,600 /(100+\mathrm{An})$ & 34.00 \\
\hline \multicolumn{2}{|c|}{} \\
\hline
\end{tabular}

Germany low energy consumption building is divided into three grades, i.e., low energy consumption building, 3L oil building and passive house. Unit usable area heat demand required by Germany low energy consumption building is $30-70 \mathrm{kWh} /\left(\mathrm{m}^{2} \cdot \mathrm{a}\right)$. Heat demand stipulated by Germany EnEV2009 is $45 \mathrm{kWh} /\left(\mathrm{m}^{2} \cdot \mathrm{a}\right)$, which is equal to low energy consumption building. Unit usable area heat demand of $3 \mathrm{~L}$ oil building is $15-30 \mathrm{kWh} /\left(\mathrm{m}^{2} \cdot \mathrm{a}\right)$. Unit usable area heat demand of passive house shall be below $15 \mathrm{kWh} /\left(\mathrm{m}^{2} \cdot \mathrm{a}\right)^{[6]}$.

Comparison of thermal parameters

Germany buildings are mainly low-rise and multi-story building ${ }^{[7]}$. In order to make building energy consumption of the two countries comparable, and residential building with 4-8 stories is selected as comparative object. Comparison results are shown in Table 3.

Table 3 Comparison of envelope thermal parameters

\begin{tabular}{|c|c|c|c|c|}
\hline \multirow{2}{*}{ Envelope position } & \multicolumn{3}{|c|}{ Heat transfer coefficient K limit value W/(m2·K) } \\
\cline { 2 - 5 } & $75 \%$ standards & $\begin{array}{c}\text { Energy } \\
\text { efficiency norm } \\
\text { EnEV2002 }\end{array}$ & $\begin{array}{c}\text { Low energy } \\
\text { consumption } \\
\text { building } \\
\text { EnEV2009 }\end{array}$ & Passive house \\
\hline Roof & 0.35 & 0.25 & 0.20 & 0.15 \\
\hline Exterior wall & 0.40 & 0.35 & 0.24 & 0.15 \\
\hline Exterior window & 2.00 & 1.50 & 1.30 & 0.80 \\
\hline Non-heating floor slab & 0.50 & 0.40 & 0.35 & 0.15 \\
\hline Overall air tightness & $/$ & $\mathrm{N}_{50}=3.0$ & $\mathrm{~N}_{50}=1.0$ & $\mathrm{~N}_{50}=0.6$ \\
\hline
\end{tabular}

By analyzing above table and considering gap between heating degree day of the two countries, it can be seen that envelope thermal performance of $75 \%$ residential building energy efficiency design standards of Shandong Province reaches the level of Germany energy efficiency norm EnEV2002. However, for building overall air tightness, Shandong Province hasn't corresponding control index. In Europe, even for residential building that uses natural ventilation, building overall air tightness control index is also controlled strictly. During calculation of energy efficiency of Shandong Province building, ventilation rate of 0.5 times/h is used during theoretical calculation value, and can't be used as the requirement on room overall air tightness really.

4 Comparison of residential heat demand

Residential building of Shandong Province and Germany residential building has large difference on boundary condition of heat demand calculation, and is summed up as following table. 
Table 4 Comparison of calculation heat demand boundary condition

\begin{tabular}{|c|c|c|}
\hline Item name & $\begin{array}{l}\text { 75\% energy efficiency } \\
\text { residential building }\end{array}$ & $\begin{array}{c}\text { Germany low energy consumption } \\
\text { building }\end{array}$ \\
\hline $\begin{array}{l}\text { Winter heating indoor } \\
\text { temperature }\end{array}$ & $18^{\circ} \mathrm{C}$ & $20^{\circ} \mathrm{C}$ \\
\hline $\begin{array}{c}\text { Winter heating } \\
\text { calculation ventilation } \\
\text { rate }\end{array}$ & $0.5 / h$ & $0.35 / \mathrm{h}$ or $30 \mathrm{~m}^{3} /$ (h.person) \\
\hline $\begin{array}{l}\text { Building inside heat } \\
\text { gain }\end{array}$ & $3.8 \mathrm{~W} / \mathrm{m}^{2}$ & $2.1 \mathrm{~W} / \mathrm{m}^{2}$ \\
\hline $\begin{array}{l}\text { Calculation heating } \\
\text { period days }\end{array}$ & 92 days & $\begin{array}{l}\text { Ensure indoor temperature, } \\
\text { without fixed time limit }\end{array}$ \\
\hline $\begin{array}{l}\text { Area used by heat } \\
\text { consumption index }\end{array}$ & Building area & Usable area \\
\hline $\begin{array}{l}\text { Heat consumption } \\
\text { index }\end{array}$ & $9.2 \mathrm{~W} / \mathrm{m}^{2}$ & 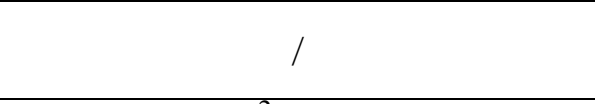 \\
\hline Heat demand & $\begin{array}{c}20.3 \mathrm{kWh} /\left(\mathrm{m}^{2} \cdot \mathrm{a}\right) \text { (calculating } \\
\text { according to heating period of } \\
92 \text { days })\end{array}$ & $\begin{array}{c}45 \mathrm{kWh} /\left(\mathrm{m}^{2} \cdot \mathrm{a}\right) \text { (low energy } \\
\text { consumption building) } \\
15 \mathrm{kWh} /\left(\mathrm{m}^{2} \cdot \mathrm{a}\right) \text { (passive house) }\end{array}$ \\
\hline
\end{tabular}

Building heat consumption index of $3.8 \mathrm{~W} / \mathrm{m}^{2}$ adopts index value stipulated by "Energy Efficiency Design Standard on Civil Buildings (Heating Residential Building Part)” issued in 1986. Living way of current residential building people, average living population and energy use way have very large difference with those in 1980s, change of these factors causes change of building internal heat source, and more rational value way of building heat consumption index shall be prepared ${ }^{[8]}$.

Ventilation rate of 0.5 times/hadopts the data stipulated by JGJ26-95 "Energy Efficiency Design Standard on Civil Buildings (Heating Residential Building Part)". The index is now that required according to the requirements of hygiene standard. Current residential building population has very large difference with that in 1990s, and the index shall be also correct.

Due to difference of boundary conditions, heat demand calculated by both of them isn't comparable. Same boundary conditions shall be used, i.e., Winter heating indoor temperature of $20^{\circ} \mathrm{C}$, Winter heating calculation ventilation rate of 0.35 times $/ \mathrm{h}$, building inside heat gain of 2.1 $\mathrm{W} / \mathrm{m}^{2}$ and usable area are used for calculating heat consumption index (building area is converted into usable area by conversion factor of 0.8 ).

Low energy consumption house is often defined as annual heating heat demand of unit usable area in unit heating degree day. By considering Germany low energy consumption standards of 45 $\mathrm{kWh} /\left(\mathrm{m}^{2} \cdot \mathrm{a}\right)$ and heating degree day of $3,500{ }^{\circ} \mathrm{C} \cdot \mathrm{d}$, according to heating degree day of $2,638{ }^{\circ} \mathrm{C} \cdot \mathrm{d}$ in Shandong Province, low energy consumption building heat demand index of Shandong Province is converted.

Calculation results are shown in Table 5. 
Table 5 Comparison of uniform calculation boundary condition heat demand

\begin{tabular}{|c|c|c|}
\hline Item name & $75 \%$ energy efficiency residential building & $\begin{array}{c}\text { Low energy consumption } \\
\text { residential building }\end{array}$ \\
\hline $\begin{array}{c}\text { Heat } \\
\text { consumption } \\
\text { index }\end{array}$ & $13.5 \mathrm{~W} / \mathrm{m}^{2}$ & / \\
\hline \multirow{3}{*}{ Heat demand } & $\begin{array}{c}29.9 \mathrm{kWh} /\left(\mathrm{m}^{2} \cdot \mathrm{a}\right) \text { (calculating according to } \\
\text { heating period of } 92 \text { days) }\end{array}$ & \multirow{2}{*}{$33.9 \mathrm{kWh} /\left(\mathrm{m}^{2} \cdot \mathrm{a}\right)$} \\
\cline { 2 - 2 } & $\begin{array}{c}39.0 \mathrm{kWh} /\left(\mathrm{m}^{2} \cdot \mathrm{a}\right)(\text { calculating according to } \\
\text { heating period of } 120 \text { days })\end{array}$ & \\
\cline { 2 - 3 } & $\begin{array}{c}44.9 \mathrm{kWh} /\left(\mathrm{m}^{2} \cdot \mathrm{a}\right)(\text { ventilation rate of } 0.5 \\
\text { times } / \mathrm{h} \text { heating period of } 120 \text { days })\end{array}$ & \\
\hline
\end{tabular}

Analysis is made by above table, if ventilation ventilation rate is same as the requirement in Germany standards, heat demand of $39.0 \mathrm{kWh} /\left(\mathrm{m}^{2} \cdot \mathrm{a}\right)$ is close to heat demand of 33.9 $\mathrm{kWh} /\left(\mathrm{m}^{2} \cdot \mathrm{a}\right)$ in low energy consumption building standards, but if ventilation ventilation rate continues use original ventilation rate of 0.5 times/h, then heat demand can't meet the requirement of low energy consumption building.

\section{Improvement routes of residential building energy efficiency design standards of Shandong Province}

By comparing to Germany energy efficiency standards, improvement routes of residential building energy efficiency design standards of Shandong Province are summed as following.

Table 6 Improvement routes of residential building design standards of Shandong Province

\begin{tabular}{|c|c|}
\hline Technical measure & Basic requirement \\
\hline $\begin{array}{l}\text { Better envelope thermal } \\
\text { performance }\end{array}$ & $\begin{array}{l}\text { Implement according to the requirements of Germany } \\
\text { EnEV2002 }\end{array}$ \\
\hline Reduce heat bridge effect & $\begin{array}{c}\text { Propose better requirement on heat bridge part treatment, } \\
\text { besides meeting the requirement on non-condensation heat } \\
\text { bridge part }\end{array}$ \\
\hline Decrease air infiltration & $\begin{array}{l}\text { Stipulate building overall air tightness index, for example, } \\
\qquad \mathrm{N}_{50}=3.0\end{array}$ \\
\hline Have organic ventilation & Ventilation system without heat recovery \\
\hline Suitable heating system & $\begin{array}{l}\text { Heating system has automatic control device with high } \\
\text { sensitivity }\end{array}$ \\
\hline Other technical measure & Heat metering and charging \\
\hline
\end{tabular}

\section{Conclusion}

1. 75\% energy efficiency design standards of Shandong Province reach the level of Germany EnEV2002 energy efficiency norm. However, it has certain gag with the level of Germany low energy consumption building.

2. Research on parameter value used by heat consumption index calculation shall be enhanced, for example, building internal heat gain and ventilation rate. Under the precondition that envelope thermal performance is improved continuously, influence of value of these index on heat demand index is increasingly bigger.

3. Residential building energy efficiency improvement level in the future shall be mainly made in various aspects such as reducing heat bridge effect, improving building overall air tightness and having organic ventilation. 


\section{References}

[1] Beijing Planning Committee. Residential Building Energy Efficiency Design Standard DB11/891-2012 [S].

[2]Shandong Provincial Department of Housing and Urban-rural Construction..Residential Building Energy Efficiency Design Standard DB37/5026-2014 [S].

[3] Hebei Provincial Department of Housing and Urban-rural Construction..Residential Building Energy Efficiency Design Standard DB13(J) 185-2015 [S].

[4] Tianjin Urban-rural Construction and Transportation Committee. Residential Building Energy Efficiency Design Standard DB29-1-2013[S].

[5] Zhang Shenshu .Analysis on Examples of Germany Low/Zero Energy Consumption Buildings [M]. 2007: China China Architecture \& Building Press.

[6] Lu Qiu. Technical System of Germany Low Energy Consumption Buildings [J].Eco-City and Green Building, Volume 1 of 2015.

[7] Qin Luofeng. Research on Development Experiences and Features of Germany Houses and Residential Areas [J]. New Building, Volume 2 of 2006.

[8] Wang Xinglong. Research on Inside Heat Gain of Residential buildings in Heating Areas [D].Xi`an University of Architecture and Technology, 2013. 